\title{
VALUE OF TRANSFORMING TOP THREE HOT DESERTS INTO AGRICULTURAL ZONES
}

Dr. Ugur Sevilmis

Eastern Mediterranean Agricultural Research Institute, Adana, Turkey

sevilmisugur@yahoo.com

\begin{abstract}
Sahara, Australia and Arabian deserts are top three hyper arid zones covering 0,9 billion, 0,27 billion and 0,23 billion ha area, respectively. On maize basis, to simlify the calculations, just grain value to be produced by transforming these three deserts is annually 2,3 trillion $\$$. Effects on $\mathrm{CO} 2$ capture, employment were also calculated. As a food source, other benefits will be the reduction of powery and conflicts; longer average life-spans; input \& product trade, economic stabilities; new markets and householders for conventional commercial and industrial products. The sophisticated activity invented in the fertile crescent -farming- may re-create the second shift in the globe to start the "Age of Arids" to end the accumulated problems of present-day. This paper is designed to show how ultra marginal zones may add high value to all humanity. Artificial rains which may be produced with current global knowldge, is the main requirement. A very small part of global research infrustructure and budget might fulfill the required knowledge to reach this target.
\end{abstract}

Keywords: Desert, transformation, agriculture, value, environment, social benefits

\section{Introduction}

Africa's population is rising the fastest. The pressure to provide work opportunities for new jobs will be particularly acute in Africa. Promoting jobs for growth, the rural economy, are addressing the needs of African economies (ILO, 2019). According to Worldbank data, unemployment (\% of total labor force, modeled ILO estimate) in SubSaharan Africa was 27\% for South Africa, 23\% for Lesotho, 23\% for Namibia, 23\% for Eswatini, $19 \%$ for Gabon, $18 \%$ for Botswana, $14 \%$ for Somalia, $13 \%$ for Sudan and $12 \%$ for Cabo Verde in 2019 (Worldbank, 2019). According to ILO (International Labour Organization), youth unemployment rate (men and women respectively) was 49 and 58\% in South Africa (in 2018); 40 and 67\% in Libya (in 2012); 44 and 53\% in Lesotho (in 2008); 30 and 41\% in Gabon (in 2010); 27 and 43\% in Sudan (in 2011); 29 and $43 \%$ in Botswana (in 2010); 37 and 38\% in Namibia (in 2018); 21 and 39\% in Algeria (in 2013); 23 and 24\% in Zambia (in 2014) (ILOSTAT, 2020).

The Sahara Desert is Earth's largest nonpolar desert, almost the size of the continental United States (NASA, 2020). With an area of approximately 9.2 million $\mathrm{km}^{2}$ it covers about $6 \%$ of the land surface area of the earth (Cook \& Vizy, 2015). Sahara $(9,2$ million km2), Australian (2,7 million km2), Arabian (2,3 million km2), Kalahari (0,9 million km2), Syrian ( 0,5 million km2), Chihuahuan (0,4 million km2), Sonoran (0,3 million km2), Thar $(0,2$ million $\mathrm{km} 2)$, Atacama $(0,1$ million $\mathrm{km} 2)$ and Mojave $(0,1$ million $\mathrm{km} 2)$ are in hot 
and mild desert category as climate which cover in total 16,5 million $\mathrm{km} 2$ (equal to 1,6 billion ha) (Anonymus, 1). Every year, each square kilometer of the desert receives solar energy equivalent to 1.5 million barrels of oil. Multiplying by the area of deserts in Africa or in the world, this is several hundred times as much energy as the world usage in a year. This means that in Africa, countries like Algeria, Angola, Libya and Nigeria can move directly from being oil-rich to being solar-rich (Anonymus, 2). Photosynthesis is the most sustainable method with its high final product diversity to exploit the solar power.

\section{Transformation of top three hot deserts}

Surface area of top three deserts are:

0,9 billion ha $+0,27$ billion ha $+0,23$ billion $\mathrm{ha}=1,4$ billion ha

To simlify the calculation, we may use maize, a highly productive $\mathrm{C} 4$ crop requiring less days to mature under hot conditions. It is possible to get two crop cycles in these zones with maize. Maize yield average of world is $5.5 \mathrm{t} / \mathrm{ha}$. We may may produce 11 t/ha with two cycles on hot deserts. On top three deserts we may obtain:

$$
1,4 \text { billion ha }{ }^{*} 11 \mathrm{t} / \mathrm{ha}=15,4 \text { billion tons of grain maize }
$$

This annual amount of grain maize with $150 \$$ /t price will equal to:

$$
15,4 \text { billion tons * } 150 \$ / t=2,3 \text { trillion } \$
$$

In the study of Wijitkosum \& Sriburi (2018), the carbon stored in biomass of maize was between 5.8 to 7.2 ton/ha with different applications where the grain yields were around $6 \mathrm{t} / \mathrm{ha}$ and biomass yield were between 12-17 t/ha. The atomic weight of carbon is 12 atomic mass units, while the weight of carbon dioxide is 44 , because it includes two oxygen atoms that each weigh 16 . So, one ton of carbon is equal to $44 / 12=3.67$ tons of carbon dioxide (Anonymus, 3). With average of $11 \mathrm{t} /$ ha grain yield per year, we may capture $9 \mathrm{t}$ carbon from a hectare, which is equal to:

$$
9 \mathrm{t} / \mathrm{ha} \mathrm{C} * 3,67=33 \mathrm{t} \mathrm{CO} / \text { ha/year }
$$

Total CO2 capture potential of top three deserts is:

$$
1,4 \text { billion ha * } 33 \text { t CO2/ha/year }=46,2 \text { billion tons (gt) CO2 }
$$

Ma et al., (2012) studied the total GHG (greenhouse gas) emissions and the contributions of $\mathrm{N}$ related factors to total GHG emissions in a 19-year field study on maize production and found that, for monoculture maize farming, $19-30 \%$ of GHG emission is sourcing from $\mathrm{N}$ production and $44-61 \%$ is from $\mathrm{N}$ application. This means that around $75 \%$ of $\mathrm{CO} 2$ emission from maize farming is sourcing from production and application of chemical fertilizers. World average carbon footprint (cradle to gate) calculated from literature (in $\mathrm{kg} \mathrm{CO} 2 \mathrm{eq} / \mathrm{per} \mathrm{kg} \mathrm{N}$ ) for DAP fertilizer is 4,52. And world average carbon footprint (cradle to gate) calculated from literature (in $\mathrm{kg} \mathrm{CO} 2 \mathrm{eq} / \mathrm{per}$ $\mathrm{kg} \mathrm{N}$ ) for urea fertilizer is 5.0 (Kool et al., 2012).

The CO2 emission from consumption and application of $500 \mathrm{~kg} / \mathrm{ha}$ DAP (18.46.0), total for two crop cycles in one year will be: 


$$
(500 * 0,18) \mathrm{kg} / \mathrm{ha} \mathrm{N} * 4,52 \mathrm{~kg} \mathrm{CO} 2 \mathrm{eq} / \text { per kg N }=406,8 \mathrm{~kg} \text { CO2eq } / \text { per ha (6) }
$$

The $\mathrm{CO} 2$ emission from consumption and application of $500 \mathrm{~kg} / \mathrm{ha}$ urea (46.0.0), total for two crop cycles in one year will be:

$$
(500 * 0,46) \mathrm{kg} / \mathrm{ha} \mathrm{N} * 5.0 \mathrm{~kg} \mathrm{CO} 2 \mathrm{eq} / \text { per kg N }=1.150 \mathrm{~kg} \mathrm{CO} \text { eq } / \text { per ha }
$$

Emission from fertilizer consumption and application is equal to $75 \%$ of total emission from maize agriculture Ma et al., (2012). So the total CO2 emission from this system will be:

$$
(1.150+406,8) / 0,75=2.076 \mathrm{~kg} \mathrm{CO} 2 \mathrm{eq} / \mathrm{per} \text { ha }
$$

On top three deserts, on 1.4 billion ha, $\mathrm{CO} 2$ emission will be:

$$
2,1 \text { t CO2 eq/per ha * } 1,4 \text { billion ha }=3 \text { billion t CO2 }
$$

Net $\mathrm{CO} 2$ capture from maize farming will be:

$$
46,2 \mathrm{gt}-3 \mathrm{gt}=43,2 \mathrm{gt} \mathrm{CO} 2
$$

Energy-related CO2 emissions rose to 33 billion tonnes (gt) in 2018 according to IEA estimates (Anonymus, 4). So, this is capable of solving global energy-related CO2 emission problem of the world.

In a study conducted in Ghana by Ngeleza et al., (2011), labor requirement for maize was found between 295-531 person-hours per acre which is equal to 737-1.327 person-hours per ha. With the lowest labour requiring system of 700 person hour per ha, with 8 hour/day, with 2 crop cycles it will require:

$$
(700 / 8) * 2=175 \text { days }
$$

This means one worker is required for two hectare of maize per year. This may promote an employment demand of:

$$
\text { ( } 1,4 \text { billion ha) } / 2=700 \text { million person per year }
$$

An estimated 172 million people worldwide were unemployed in 2018, which corresponds to an unemployment rate of 5.0 per cent according to ILO, (2020). Worker deficit may be compensated by entrance of new persons in labour market and mechanisation.

\section{Results}

Transforming top three deserts -Sahara, Australia and Arabian deserts- to agricultural zones, may produce 2,3 trillion $\$$ annually just as harvested grain. Net CO2 capture from this system may have a potential of $43,2 \mathrm{gt} \mathrm{CO} 2$ which is capable of absorbing current global energy-related $\mathrm{CO} 2$ emission. Total unemployment will be zero where new jobs and improved mechanisation will be required with the transformation. Other benefits will be the reduction of hunger, powery and conflicts; longer average lifespans; input \& product trade, economic stabilities; new markets and householders for conventional commercial and industrial products. 
Global research insfrastructure is conducting many R\&D activities and discovering important research results where most of these novel techniques and biotic or abiotic products have important capacity and value for these sand based environmental conditions.

\section{Literatures}

Anonymus. 1. https://en.wikipedia.org/wiki/List of deserts by area

Anonymus. 2. https://gailvoice.com/an-abundant-clean-source-of-energy-desertsec/

Anonymus. 3. https://thinkprogress.org/the-biggest-source-of-mistakes-c-vs-co2c0b077313b/

Anonymus. 4. https://www.reuters.com/article/us-iea-emissions/global-carbonemissions-hit-record-high-in-2018-iea-idUSKCN1R7005

Cook, K. H., \& Vizy, E. K. (2015). Detection and analysis of an amplified warming of the Sahara Desert. Journal of Climate, 28(16), 6560-6580.

ILO. (2019). https://www.ilo.org/africa/about-us/lang--en/index.htm

ILO. (2020). https://www.ilo.org/wcmsp5/groups/public/---dgreports/---dcomm/--publ/documents/publication/wcms 670554.pdf

ILOSTAT, 2020. https://ilostat.ilo.org/data/country-profiles/

Kool, A., Marinussen, M., \& Blonk, H. (2012). LCl data for the calculation tool Feedprint for greenhouse gas emissions of feed production and utilization. GHG Emissions of $N, P$ and $K$ fertiliser production.

Ma, B. L., Liang, B. C., Biswas, D. K., Morrison, M. J., \& McLaughlin, N. B. (2012). The carbon footprint of maize production as affected by nitrogen fertilizer and maizelegume rotations. Nutrient Cycling in Agroecosystems, 94(1), 15-31.

NASA, 2020. https://earthdata.nasa.gov/learn/sensing-our-planet/out-of-africa

Ngeleza, G. K., Owusua, R., Jimah, K., \& Kolavalli, S. (2011). Cropping practices and labor requirements in field operations for major crops in Ghana. What Needs to Be Mechanized? International Food Policy Research Institute, Development Strategy and Governance Division.

Wijitkosum, S., \& Sriburi, T. (2018). Increasing the amount of biomass in field crops for carbon sequestration and plant biomass enhancement using biochar. In Biochar-An Imperative Amendment for Soil and the Environment. IntechOpen.

Worldbank.

https://data.worldbank.org/indicator/SL.UEM.TOTL.ZS?locations=ZG 